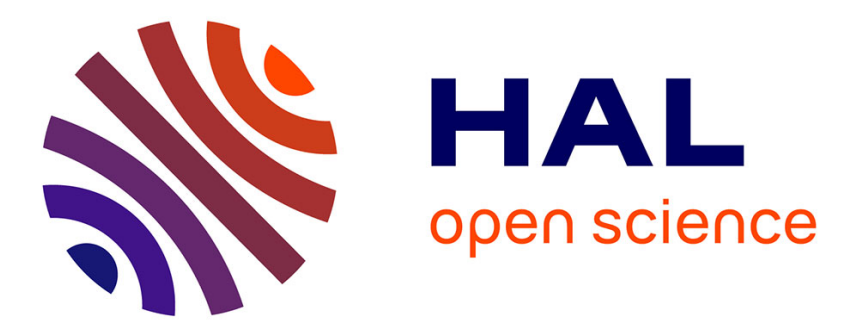

\title{
Shiga toxin-producing Escherichia coli-associated hemolytic uremic syndrome in solid organ transplant recipients
}

Simon Ville, Amandine Ydee, Claire Garandeau, Emmanuel Canet, Adrien

Tissot, Diego Cantarovich, Véronique Frémeaux-Bacchi, Patricia

Mariani-Kurkdjian, François Provôt, Fadi Fakhouri

\section{To cite this version:}

Simon Ville, Amandine Ydee, Claire Garandeau, Emmanuel Canet, Adrien Tissot, et al.. Shiga toxinproducing Escherichia coli-associated hemolytic uremic syndrome in solid organ transplant recipients. Kidney International, 2019, 96 (6), pp.1423-1424. 10.1016/j.kint.2019.08.024 inserm-02419947

\section{HAL Id: inserm-02419947 https://www.hal.inserm.fr/inserm-02419947}

Submitted on 19 Dec 2019

HAL is a multi-disciplinary open access archive for the deposit and dissemination of scientific research documents, whether they are published or not. The documents may come from teaching and research institutions in France or abroad, or from public or private research centers.
L'archive ouverte pluridisciplinaire HAL, est destinée au dépôt et à la diffusion de documents scientifiques de niveau recherche, publiés ou non, émanant des établissements d'enseignement et de recherche français ou étrangers, des laboratoires publics ou privés. 
Medicine, and Center for Molecular Medicine Cologne, University of Cologne, Cologne, Germany; ${ }^{5}$ Center for Mass Spectrometry and Metabolomics, The Scripps Research Institute, La Jolla, California, USA; ${ }^{6}$ RWTH Aachen University, Department of Nephrology and Clinical Immunology, Aachen, Germany; and ${ }^{7}$ Department of Internal Medicine, Nephrology and Transplantation, Erasmus Medical Center, Rotterdam, The Netherlands

Correspondence: Julio Saez-Rodriguez, Institute for Computational Biomedicine, Heidelberg University, Faculty of Medicine, and Heidelberg University Hospital, BioQuant, Im Neuenheimer Feld 267, 69120 Heidelberg, Germany.E-mail: julio.saez@bioquant.uni-heidelberg.de; or Rafael Kramann, RWTH Aachen University, Department of Nephrology and Clinical Immunology, Pauwelstrasse 30, 52074 Aachen, Germany. E-mail:

rkramann@gmx.net

Kidney International (2019) 96, 1422-1423; https://doi.org/10.1016/ j.kint.2019.09.011

Copyright (c) 2019, International Society of Nephrology. Published by Elsevier Inc. All rights reserved.

\section{Shiga toxin-producing Escherichia coli-associated hemolytic uremic syndrome in solid organ transplant recipients}

To the editor: Shiga toxin-producing Escherichia coli-associated hemolytic uremic syndrome (STEC-HUS) has been very rarely documented in solid organ transplantation patients. ${ }^{1}$ We report a series of 5 solid organ transplantation recipients diagnosed with STEC-HUS between January 2017 and March 2019 in 2 French nephrology centers (Table 1). One patient had 2 episodes of STEC-HUS. All had severe acute kidney injury (requiring hemodialysis in 2).

Table 1 | Characteristics of 5 solid organ transplant recipients with STEC-HUS

\begin{tabular}{|c|c|c|c|c|c|c|c|c|c|c|c|c|c|c|c|}
\hline \multicolumn{16}{|c|}{ STEC-HUS features } \\
\hline $\mathrm{Pt}$ & $\begin{array}{l}\text { Sex, } \\
\text { age } \\
\text { (y) }\end{array}$ & $\begin{array}{c}\text { SOT } \\
\text { (primary } \\
\text { disease) }\end{array}$ & $\begin{array}{l}\text { Time } \\
\text { since } \\
\text { SOT } \\
\text { (mo) }\end{array}$ & $I^{\mathrm{a}}$ & $\begin{array}{c}\text { Baseline } \\
\mathrm{SCr} \\
(\mathrm{mg} / \mathrm{dl}) / \\
\text { eGFR } \\
(\mathrm{ml} / \mathrm{min} \\
\mathrm{per} \\
\left.1.73 \mathrm{~m}^{2}\right)\end{array}$ & $\begin{array}{c}\text { Maximal } \\
\text { SCr } \\
(\mathrm{mg} / \mathrm{dl})\end{array}$ & $\begin{array}{l}\text { Plt } \\
(g / l)\end{array}$ & $\begin{array}{l}\mathrm{Hb}^{\mathrm{b}} \\
(\mathrm{g} / \mathrm{dl})\end{array}$ & $\begin{array}{l}\text { LDH } \\
(x U L N)\end{array}$ & $\begin{array}{l}U \mathrm{P} / \mathrm{Cr} \\
(\mathrm{g} / \mathrm{g})\end{array}$ & $\begin{array}{c}\text { Extrarenal } \\
\text { manifestations }\end{array}$ & $\begin{array}{c}E \text { coli } \\
\text { serotype }\end{array}$ & Stx & Treatment & Outcome \\
\hline 2 & $F, 49$ & $\begin{array}{l}\text { Pancreas } \\
\text { (type } 1 \\
\text { diabetes) }\end{array}$ & 41 & $\begin{array}{c}\text { Tac } \\
{[2.2]+} \\
\mathrm{AZA}+ \\
\mathrm{Cs}\end{array}$ & $1.6 / 36$ & 8.5/HD & 20 & 8.1 & 7 & 21 & $\begin{array}{l}\text { Watery diarrhea, } \\
\text { confusion/tremor, } \\
\text { myocardial } \\
\text { ischemia }\end{array}$ & $\mathrm{O} 157 \mathrm{H} 7$ & Stx2 & $\begin{array}{c}\text { Tac + AZA } \\
\text { discontinuation } \\
\mathrm{PI}+\text { Ecu (4) }\end{array}$ & $\begin{array}{c}\text { Partial renal } \\
\text { recovery } \\
(\mathrm{SCr} 2.1 \mathrm{mg} \\
\left.\mathrm{dl}^{\mathrm{d}}\right)^{\mathrm{d}}\end{array}$ \\
\hline 4 & $F, 38$ & $\begin{array}{l}\text { Lung } \\
\text { (cystic } \\
\text { fibrosis) }\end{array}$ & 21 & $\begin{array}{c}\text { Tac } \\
{[10]+} \\
\text { MMF }+ \\
\text { Cs }\end{array}$ & $2.2 / 27$ & 4.6 & 39 & 7.2 & 2.8 & 1 & $\begin{array}{c}\text { Pancolitis, } \\
\text { myoclonia/coma }\end{array}$ & NA & Stx2 & $\begin{array}{c}\text { Switch Tac/ } \\
\text { CSA } \\
\text { Ecu (2) }\end{array}$ & $\begin{array}{l}\text { Decrease of } \\
\mathrm{SCr} \text { to } \\
\text { baseline } \\
\text { values } \\
(2.5 \mathrm{mg} / \mathrm{dl})^{\mathrm{d}}\end{array}$ \\
\hline \multirow[t]{2}{*}{5} & $F, 25$ & $\begin{array}{l}\text { Lung } \\
\text { (cystic } \\
\text { fibrosis) }\end{array}$ & 57 & $\begin{array}{c}\text { Tac } \\
{[\mathrm{NA}]+} \\
\mathrm{MPA}+ \\
\mathrm{Cs}\end{array}$ & $1.8 / 36$ & 7.2 & 99 & 8.3 & 3.5 & 0.7 & $\begin{array}{l}\text { Watery diarrhea, } \\
\text { colitis, confusion/ } \\
\text { generalized } \\
\text { seizures }\end{array}$ & 0156 & Stx1 & $\begin{array}{l}\text { Transient Tac } \\
\text { withdrawal } \\
\text { (3 d) }\end{array}$ & $\begin{array}{l}\text { Decrease of } \\
\text { SCr to } \\
\text { baseline } \\
\text { values } \\
(\mathrm{mg} / \mathrm{dl})^{\mathrm{d}}\end{array}$ \\
\hline & & & 64 & $\begin{array}{c}\text { Tac } \\
{[3.4]+} \\
\text { MPA }+ \\
\text { Cs }\end{array}$ & $1.8 / 36$ & $4.3 / \mathrm{HD}$ & 83 & 7.5 & 3.3 & 8.8 & $\begin{array}{c}\text { Diarrhea/pancolitis, } \\
\text { confusion/ } \\
\text { generalized } \\
\text { seizures }\end{array}$ & NA & Stx1 & $\begin{array}{c}\text { Switch Tac/ } \\
\text { CSA } \\
\text { Ecu (4) }\end{array}$ & $\begin{array}{l}\text { Chronic } \\
\text { dialysis }\end{array}$ \\
\hline
\end{tabular}

AZA, azathioprine; Cs, corticosteroids; Ecu, eculizumab (number of infusions; dosage was $900 \mathrm{mg} / \mathrm{wk}$ ); eGFR, glomerular filtration rate estimated using the Modification of Diet in Renal Disease formula; F, female; Hb, hemoglobin; HD, hemodialysis; IS, immunosuppressors; KB, kidney biopsy; LDH, lactate dehydrogenase; M, male; MMF, mycophenolate mofetil; NA, not available; PCR, polymerase chain reaction; PI, plasma infusion; Plt, platelet count; Pt, patient; SCr, serum creatinine; SOT, solid organ transplantation; STEC-HUS, Shiga toxin-producing Escherichia coli-associated hemolytic uremic syndrome; Stx, Shiga toxin; Tac, tacrolimus; TMA, thrombotic microangiopathy; U P/Cr, urinary protein/ creatinine ratio.

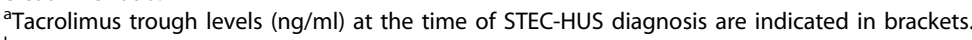

${ }^{b}$ All patients had schizocytes on a blood smear and an undetectable serum haptoglobin level.

'In all cases, STEC infection was confirmed by multiplex PCR (commercial assay) for $\operatorname{stx} 1(n=1)$ and $\operatorname{stx} 2(n=4)$.

${ }^{\mathrm{d}} \mathrm{Scr}$ at last follow-up.

In all patients, C3, C4, and CH50 serum levels were normal, and ADAMTS13 plasma activity was $>10 \%$. None had donor-specific antibodies or detectable cytomegalovirus plasma replication. Kidney biopsy performed in patients 1 (renal graft) and 5 (second episode) disclosed extensive lesions of TMA (thrombi in arterioles and glomerular capillaries). No patient had genetic testing for variants in complement genes. 
Neurological involvement was noted during 5 episodes: seizures $(n=4)$ and confusion/coma $(n=4)$. Patient 2 (Table 1 ), with type 1 diabetes but no history of coronaropathy, had acute elevation of serum level of troponin T (8119 ng/l; normal $<14$ ) with normal coronary angiography. All patients had detectable $(>10 \%)$ serum ADAMTS13 activity. After STEC-HUS diagnosis, the immunosuppressive regimen was amended in 4 patients. Four patients were treated with eculizumab because of severe renal and/or extrarenal manifestations. One patient had a partial renal recovery, 2 regained their baseline renal function, and 2 progressed to end-stage renal disease.

To the best of our knowledge, this is the first case series of STEC-HUS in solid organ transplantation patients. STEC-HUS is probably underdiagnosed in this setting because diarrhea and thrombotic microangiopathy are usually attributed to causes other than STEC infections (immunosuppressive drugs, non-STEC infections, recurrence of atypical HUS, humoral rejection). Clinicians should be aware that STEC-HUS is a potential severe form of thrombotic microangiopathy in solid organ transplantation patients. Systematic screening for Shiga toxin in stool using preferentially polymerase chain reaction ${ }^{2}$ is recommended even in the presence of only mild digestive symptoms. Several issues regarding the management of STEC-HUS in these patients warrant further assessment, especially the discontinuation of anticalcineurin and mammalian target of rapamycin inhibitors and the potential use of complement inhibitors. The use of eculizumab during 4 episodes in our series was empirical. In contrast to atypical HUS, STEC-HUS has not been linked to a constitutional or acquired dysregulation of the complement alternative pathway, ${ }^{3}$ and screening for variants in complement genes is not usually performed in STEC-HUS patients (as in the present series). The available clinical experience with eculizumab in STEC-HUS has yielded contrasting results. ${ }^{4}$ The relevance of this complement inhibitor in STEC-HUS is currently assessed in a prospective trial (NCT01410916).

\section{DISCLOSURE}

VF-B has received consultancy fees and travel grants from Alexion, Apellis, and Roche. FP has received consultancy fees and travel grants from Alexion. FF has received consultancy fees and travel grants from Alexion, Achillion, Apellis, and Roche. All the other authors declared no competing interests.

1. Maniere L, Domenger C, Camara B, et al. An atypical case of Shiga toxin producing-Escherichia coli hemolytic and uremic syndrome (STEC-HUS) in a lung transplant recipient. Case Rep Transplant. 2019;2019:9465040.

2. Qin $X$, Klein EJ, Galanakis E, et al. Real-time PCR assay for detection and differentiation of Shiga toxin-producing Escherichia coli from clinical samples. J Clin Microbiol. 2015;53:2148-2153.

3. Fremeaux-Bacchi V, Sellier-Leclerc AL, Vieira-Martins P, et al. Complement gene variants and Shiga toxin-producing Escherichia coli-associated hemolytic uremic syndrome: retrospective genetic and clinical study. Clin J Am Soc Nephrol. 2019;14:364-377.

4. Menne J, Nitschke M, Stingele R, et al. Validation of treatment strategies for enterohaemorrhagic Escherichia coli 0104:H4 induced haemolytic uraemic syndrome: case-control study. BMJ. 2012;345:e4565.
Simon Ville ${ }^{1,2}$, Amandine Ydee $^{3}$, Claire Garandeau ${ }^{2}$, Emmanuel Canet ${ }^{4}$, Adrien Tissot ${ }^{1,5}$, Diego Cantarovich ${ }^{1,2}$, Véronique Frémeaux-Bacchi ${ }^{6}$, Patricia MarianiKurkdjian ${ }^{7}$, François Provôt ${ }^{2}$ and Fadi Fakhouri, ${ }^{1,2}$ ${ }^{1}$ Centre de Recherche en Transplantation et en Immunologie UMR 1064, INSERM, Université de Nantes, Nantes, France; ${ }^{2}$ Department of Nephrology and Immunology, Center Hospitalier Universitaire de Nantes, Nantes, France; ${ }^{3}$ Department of Nephrology, Centre Hospitalier Universitaire de Lille, Lille, France; ${ }^{4}$ Intensive Medicine Unit, Centre Hospitalier Universitaire de Nantes, Nantes, France; ${ }^{5}$ Department of Pneumology, Centre Hospitalier Universitaire de Nantes, Nantes, France; ${ }^{6}$ INSERM UMR S1138, Complément et Maladies, Centre de recherche des Cordeliers and Laboratory of Immunology, Hôpital Européen Georges Pompidou, Paris, France; and ${ }^{7} A P-H P$, Hôpital Robert Debré, CNR Escherichia coli, F-75019 Paris, France

Correspondence: Fadi Fakhouri, Department of Nephrology, Centre Hospitalier Universitaire de Nantes, 30 Boulevard Jean Monnet, 44000, Nantes,

France.E-mail: fadi.fakhouri@univ-nantes.fr

Kidney International (2019) 96, 1423-1424; https://doi.org/10.1016/ j.kint.2019.08.024

Copyright (c) 2019, International Society of Nephrology. Published by Elsevier Inc. All rights reserved.

\section{Measuring systolic and diastolic blood pressure in rodents}

To the editor: The recently conducted debate on tail-cuff versus telemetry blood pressure (BP) measurements helps both clinicians and basic scientists place reporting of $\mathrm{BP}$ in experimental studies in perspective. ${ }^{1-3}$

What I would like to add is that the tail-cuff is certainly useful for systolic BP under the conditions stipulated by Drüeke and Devuyst, ${ }^{3}$ but the diastolic BP reading is much less reliable. ${ }^{4}$ So tail-cuff BP data should, in my opinion, be restricted to systolic BP. This is well known to basic scientists as reflected by hits in PubMed: 782 for "systolic tail cuff pressure rats" versus 129 for "diastolic tail cuff pressure rats" and 122 for "systolic tail cuff pressure mice" versus 27 for "diastolic tail cuff pressure mice."

A thin, polyvinyl chloride, fluid-filled catheter with an external pressure transducer (often used in terminal experiments) tends to dampen the pulse, so the "mean" arterial pressure is fine, but systolic BP tends to be underestimated and diastolic BP overestimated. This also means that the mean arterial pressure value thus obtained is not the same as the conventionally calculated mean arterial pressure from the Riva-Rocci method.

Telemetry catheters have transducers at their tip and give reliable systolic BP and diastolic BP recordings in rats and mice. ${ }^{5,6}$ They are indispensable for analysis of complex phenomena such as circadian rhythms. ${ }^{7}$

1. Luft FC. Men, mice, and blood pressure: telemetry? Kidney Int. 2019;96: 31-33.

2. Luther JM, Fogo AB. Under pressure-how to assess blood pressure in rodents: tail-cuff? Kidney Int. 2019;96:34-36. 